\title{
Secondary organic aerosol formation from phenolic compounds in the absence of $\mathrm{NO}_{\mathrm{x}}$
}

\author{
S. Nakao ${ }^{1,2}$, C. Clark ${ }^{1,2}$, P. Tang ${ }^{1,2}$, K. Sato ${ }^{2, *}$, and D. Cocker III ${ }^{1,2}$ \\ ${ }^{1}$ University of California, Riverside, Department of Chemical and Environmental Engineering, USA \\ ${ }^{2}$ College of Engineering - Center for Environmental Research and Technology (CE-CERT), USA \\ *currently at: National Institute for Environmental Studies, Japan
}

Received: 4 December 2010 - Published in Atmos. Chem. Phys. Discuss.: 20 January 2011

Revised: 24 May 2011 - Accepted: 17 October 2011 - Published: 27 October 2011

\begin{abstract}
SOA formation from benzene, toluene, $m$-xylene, and their corresponding phenolic compounds were investigated using the UCR/CE-CERT Environmental Chamber to evaluate the importance of phenolic compounds as intermediate species in aromatic SOA formation. SOA formation yield measurements coupled to gas-phase yield measurements indicate that approximately $20 \%$ of the SOA of benzene, toluene, and $m$-xylene could be ascribed to the phenolic route under low $\mathrm{NO}_{\mathrm{x}}$ conditions. The SOA densities tend to be initially as high as approximately $1.8 \mathrm{~g} \mathrm{~cm}^{-3}$ and eventually reach the range of $1.3-1.4 \mathrm{~g} \mathrm{~cm}^{-3}$. The final SOA density was found to be independent of elemental ratio $(\mathrm{O} / \mathrm{C})$ indicating that applying constant density (e.g., $1.4 \mathrm{~g} \mathrm{~cm}^{-3}$ ) to SOA formed from different aromatic compounds tested in this study is a reasonable approximation. Results from a novel on-line PILS-TOFMS (Particle-into-Liquid Sampler coupled with Agilent Time-of-Flight Mass Spectrometer) are reported. Major signals observed by the on-line/off-line Agilent TOFMS indicated that products had the same number of carbon atoms as their parent aromatics, suggesting importance of ring-retaining products or ring-opening products following ring-cleavage.
\end{abstract}

\section{Introduction}

Secondary organic aerosol (SOA) is formed from oxidative processing of volatile organic compounds in the atmosphere. SOA has been suggested to contribute to climate change (IPCC, 2007; Kanakidou et al., 2005), adverse human health effects (Davidson et al., 2005; Pope and Dockery, 2006), and a reduction in visibility (Eldering and Cass, 1996). Previous

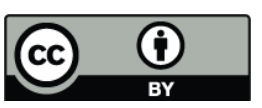

Correspondence to: D. Cocker III (dcocker@engr.ucr.edu) researchers have estimated approximately $70 \%$ of organic aerosols are secondary in nature (Hallquist et al., 2009 and references therein). Aromatic hydrocarbons comprise $20 \%$ of nonmethane hydrocarbons in the urban atmosphere and are considered to be one of the major precursors to urban SOA (Calvert et al., 2002).

A number of studies have investigated gas-phase photooxidation of aromatic hydrocarbons (e.g., Arey et al., 2009; Calvert et al., 2002; Coeur-Tourneur et al., 2006; Johnson et al., 2004; Johnson et al., 2005; Olariu et al., 2002; Takekawa et al., 2003; Volkamer et al., 2002). Previously identified first generation products of aromatic compound photooxidation explain approximately $50 \%$ of carbon balance (Calvert et al., 2002). Although multigenerational reactions have been suggested to contributed to aromatic SOA formation (Hurley et al., 2001; Ng et al., 2007; Sato et al., 2007), the extent of the contribution from the second or further reaction products to SOA is poorly understood.

Phenolic compounds are one of the major first generation products of $\mathrm{OH}$ reaction with aromatic hydrocarbons (Calvert et al., 2002). Previous studies suggested the major gas-phase reaction products from $\mathrm{OH}$ reaction of phenolics are dihydroxy compounds (e.g., $80 \%$ catechol formation from phenol, Olariu et al., 2002). However, the mechanisms of SOA formation from phenolic compounds are highly uncertain. In addition, since phenolic compounds are significant products in wood smoke (Hawthorne et al., 1989, 1992; Schauer et al., 2001; Simoneit, 1999), the reaction mechanism of phenolic compounds leading to SOA formation is of a great interest (Chang and Thompson, 2010; CoeurTourneur et al., 2010a, 2010b; Grosjean, 1984; Henry et al., 2008; Iinuma et al., 2010; Sun et al., 2010).

SOA formation from individual aromatic and phenolic compounds were investigated using an environmental chamber under low $\mathrm{NO}_{\mathrm{x}}$ (and high $\mathrm{HO}_{2}$ ) conditions to evaluate the role of phenolic species in SOA formation from aromatic

Published by Copernicus Publications on behalf of the European Geosciences Union. 
hydrocarbons. Chemical analysis was performed using online and off-line mass spectrometry to infer the structure of aromatic and phenolic SOA.

\section{Experimental}

\subsection{Environmental chamber}

Most of the experiments were conducted in the UC Riverside/CE-CERT environmental chamber described in detail in Carter et al. (2005). In short, this facility consists of dual $90 \mathrm{~m}^{3}$ Teflon ${ }^{\circledR}$ reactors suspended by rigid frames in a temperature controlled enclosure $\left(27 \pm 1^{\circ} \mathrm{C}\right)$ continuously flushed with dry (a dew point below $-40^{\circ} \mathrm{C}$ ) purified air generated by an Aadco 737 series (Cleves, Ohio) air purification system. The top frames are slowly lowered during the experiments to maintain a slight positive differential pressure $\left(0.03^{\prime \prime} \mathrm{H}_{2} \mathrm{O}\right)$ between the reactors and enclosure to minimize dilution and possible contamination of the reactors. $272115 \mathrm{~W}$ Sylvania 350 black lights are used as the light source for all the experiments reported herein.

Some of the results of dimethylphenols (DMPs) were acquired in the UCR/CE-CERT mezzanine chamber (Nakao et al., 2011). The UCR/CE-CERT mezzanine chamber is within a $2.5 \mathrm{~m} \times 3 \mathrm{~m} \times 7.8 \mathrm{~m}$ enclosure covered with reflective aluminum sheets and is illuminated with $170,40 \mathrm{~W}$ blacklights with peak intensity at $350 \mathrm{~nm}$ (SYLVANIA, $350 \mathrm{BL}$ ) with the $\mathrm{NO}_{2}$ photolysis rate of $0.6 \mathrm{~min}^{-1}$. Within this enclosure is a $12 \mathrm{~m}^{3}$ volume 2 mil FEP Teflon ${ }^{\circledR}$ film reactor. A minimum of $1 \mathrm{~m}$ space between the reactor surface and blacklights avoids excessive heating at the surface of the film. Additionally, six fans are used to mix the air inside the enclosure with room air to minimize heating in the enclosure. Prior to each experiment, the bag is flushed overnight with purified air. Background particle concentration is below the detection limit of $0.2 \mathrm{~cm}^{-3}$.

\subsection{Gas and particle analysis}

The Agilent 6890 Gas Chromatograph - Flame Ionization Detector was used to measure concentrations of reactants and products. All phenolic compounds were analyzed by a GC equipped with a thermal desorption system (CDS analytical, ACEM9305, Sorbent Tube MX062171 packed with TenaxTA/Carbopack/Carbosieve S111) except for dimethylphenols for mezzanine chamber experiments. Aromatic hydrocarbon measurements were calibrated using a dilute gas cylinder (SCOTT-MARIN, Inc) or by introducing known amount of liquid hydrocarbons into the reactor. Calibration for phenolic compounds was performed by impregnation of the glass cartridges with known quantities of phenolic compounds in acetonitrile. The Ionicon Proton Transfer Reaction Quadrupole Mass Spectromer (PTR-MS) was used to measure dimethylphenol decay for mezzanine chamber experiments.
Particle size distribution between $27 \mathrm{~nm}$ and $686 \mathrm{~nm}$ was monitored by a custom built Scanning Mobility Particle Sizer (SMPS) similar to that described by Cocker et al. (2001). Particle effective density was measured with an Aerosol Particle Mass Analyzer (APM, Kanomax) (Ehara et al., 1996) and SMPS in series. The APM is located upstream of the SMPS for improved time resolution and sensitivity $(\mathrm{S} / \mathrm{N})$ over the more common configuration of Differential Mobility Analyzer (DMA) - APM (Khalizov et al., 2009; McMurry et al., 2002; Xue et al., 2009). A detailed description of the APM-SMPS system and data algorithms are described elsewhere (Malloy et al., 2009).

The high resolution time-of-flight aerosol mass spectrometer (HR-ToF-AMS) (DeCarlo et al., 2006) was operated in high resolution W mode. Elemental analysis (EA) was used to determine the atomic ratio $(\mathrm{O} / \mathrm{C})$ of non-refractory organic aerosols (Aiken et al., 2008).

The Agilent 6210 Accurate-Mass Time-of-Flight Mass Spectrometer equipped with multimode ionization source for electrospray and atmospheric pressure chemical ionization (ESI/APCI-TOFMS) is used to obtain accurate mass of analytes. Soft ionization by ESI and APCI provides lower fragmentation of the analytes compared to electron impact (EI) used for the HR-ToF-AMS or other conventional GC-MS techniques. Mass accuracy is routinely calibrated by standard compounds (Agilent low concentration MMI tuning mix, G1969-85020) before analysis and in most cases mass accuracy of less than $5 \mathrm{ppm}$ is achieved. Occasionally higher mass errors $(\sim 30 \mathrm{ppm})$ were observed during sample analysis, which resulted in a consistent shift of mass throughout the mass range of the instrument. Since the extent of the shift can be inferred from repeatedly observed ions (e.g., pyruvic acid), formulas were carefully assigned based on tendency of shift and repeat experiments. Filter samples were collected onto Teflo® filters $(2 \mu \mathrm{m}, 47 \mathrm{~mm}$, PALL Life Sciences) at $251 \mathrm{~min}^{-1}$ for $1 \sim 4 \mathrm{~h}$. After collection, filters were stored in a freezer until extraction. Extractions were achieved by sonicating the filter in $5 \mathrm{ml}$ of acetonitrile. The extract volume was reduced under a gentle stream of $\mathrm{N}_{2}$ until near dryness and reconstituted by $300 \mu \mathrm{l}$ of acetonitrile/water/acetic acid $(50 / 50 / 0.1 \mathrm{v})$. Samples were directly infused to the TOFMS. A: water $(0.1 \mathrm{v} \%$ acetic acid $)$ and $B$ : acetonitrile were used as eluents (B $50 \%, 0.5 \mathrm{ml} \mathrm{min}^{-1}$ ). Acetonitrile was chosen as the organic solvent to reduce the solvent-analyte reaction compared to methanol (Bateman et al., 2008). Mixed mode ionization (simultaneous APCI and ESI) was used with vaporizer temperature $200^{\circ} \mathrm{C}$, nebulizer pressure $40 \mathrm{psig}$, corona current $2 \mu \mathrm{A}$, fragmentor voltage $100 \mathrm{~V}$. Although the mixed mode is used to survey a wide range of products, the resulting major signals were the same as in ESI only. APCI yielded lower sensitivity in this study. All Agilent TOFMS data was acquired in negative ion mode.

A Particle-Into-Liquid-Sampler (PILS) (Orsini et al., 2003; Weber et al., 2001) was interfaced with the TOFMS to provide an on-line accurate mass analysis of water soluble 
organic compounds (Bateman et al., 2010). In order to couple the PILS (Brechtel Manufacturing Inc.) to the TOFMS, the use of HPLC pumps in addition to a commonly used peristaltic pump was critical to overcome the backpressure of the TOFMS inlet and to supply steady flow of water $(18.2 \mathrm{M} \Omega$, Milli-Q, Millipore) into the boiler. The PILS-TOFMS system will be described in more detail in an upcoming publication (Clark et al., 2011). The negative ESI was used as the ionization method with similar conditions as the filter analysis without the corona current.

\subsection{Chamber experiments}

The experimental test matrix is summarized in Table 1. A known volume of high purity liquid aromatic hydrocarbon (All purchased from Sigma-Aldrich: $\geq 99 \%$ or $\geq 99.5 \%$, except 2,4 -DMP $\geq 98 \%$ ) was injected through a heated glass injection manifold system and flushed into the chamber with pure $\mathrm{N}_{2}$. Since phenolic compounds are less volatile than hydrocarbons typically used for chamber experiments, injection into the chambers were carefully performed using a heated oven $\left(50 \sim 80^{\circ} \mathrm{C}\right)$ through a heated transfer line maintained at a temperature higher than the oven. The glass manifold inside the oven was packed with glass wool to increase the mass transfer surface area. Since reasonable agreement between the calculated concentration of phenolics (based on injected amount) and observed concentrations were confirmed, loss of phenolics in the transfer line and to the wall was assumed to be negligible. $\mathrm{H}_{2} \mathrm{O}_{2}$ was used as an $\mathrm{OH}$ (and $\mathrm{HO}_{2}$ ) radical source. $\mathrm{H}_{2} \mathrm{O}_{2} 50 \mathrm{wt} \%$ solution was injected through the same oven system. Since the $\mathrm{H}_{2} \mathrm{O}_{2}$ solution did not spread through glass wool, the glass wool was processed with an acid/base bath and cleaned by water and acetone which enabled the $\mathrm{H}_{2} \mathrm{O}_{2}$ solution to spread. Initial $\mathrm{H}_{2} \mathrm{O}_{2}$ concentration was not measured, but is estimated to be $1 \sim 5 \mathrm{ppm}$ based on amount injected and hydrocarbon decay rate. No seed particles were used in this study. Exponential decay rates of particle number is used to calculate particle volume wall loss (Carter et al., 2005). To investigate the role of organic peroxides, additional high NO experiments were also performed and the chemical composition of SOA was compared to low $\mathrm{NO}_{\mathrm{x}}$ condition. Initial ratio of approximately $50 / 50 / 500 \mathrm{ppb}$ for phenolic/methyl nitrite/NO was used to ensure that excess $\mathrm{NO}$ was present to suppress $\mathrm{RO}_{2}+\mathrm{HO}_{2}$ reaction.

\section{Results and discussion}

\subsection{SOA formation}

SOA yield $(Y)$ is defined as the mass of aerosol formed (wallloss-corrected) $\left(M_{o}\right)$ divided by mass of hydrocarbon reacted $(\Delta \mathrm{HC})$

$Y=\frac{M_{o}}{\Delta \mathrm{HC}}$

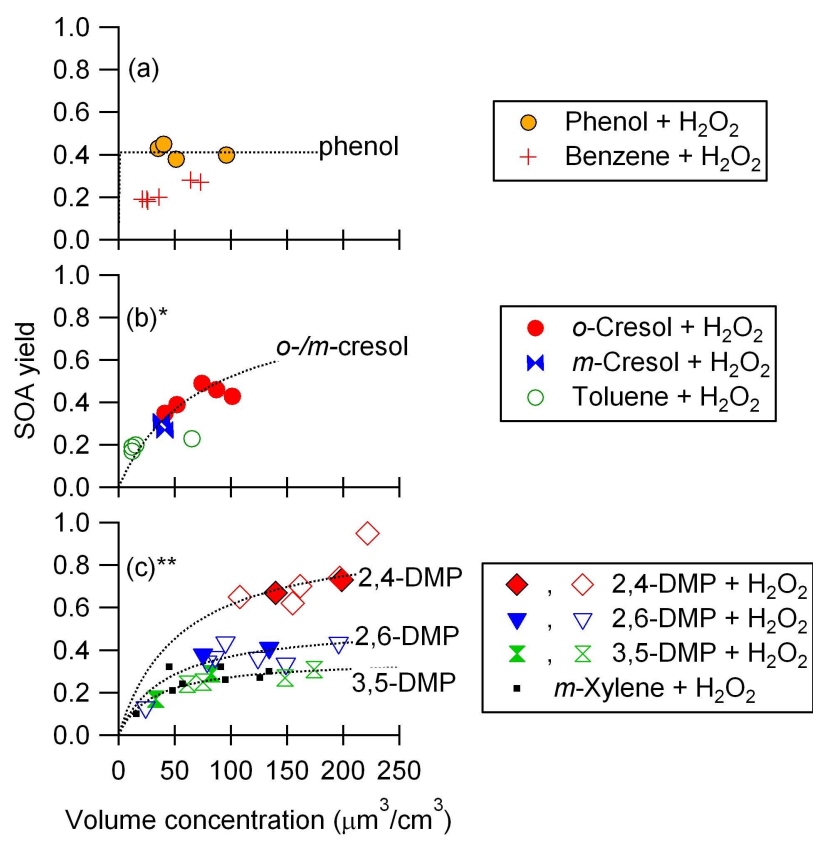

Fig. 1. SOA yield of benzene, toluene, $m$-xylene, and their phenolic compounds in the absence of $\mathrm{NO}_{\mathrm{x}}$ (Dotted lines are one product model fit for phenolic compounds). * SOA yields from cresols isomers are combined. $* *$ Open symbols are data acquired in CECERT mezzanine chamber.

Its dependence on aerosol mass loading has been traditionally parameterized by as shown below: (Odum et al., 1996)

$Y=\sum Y_{i}=M_{o} \sum_{i} \frac{\alpha_{i} K_{i}}{1+M_{o} K_{i}}$

where $\alpha_{i}$ is the mass-based stoichiometric coefficient for the reaction generating product $i, K_{i}$ is the partitioning coefficient of product $i$. Equations (1) and (2) were applied for the SOA yields obtained (Fig. 1). Particle density of $1.4 \mathrm{~g} \mathrm{~cm}^{-3}$ was used. 2,4-DMP had the highest SOA formation potential of the three DMP isomers, with a SOA yield approximately twice as high as the other DMP isomers. SOA yield from phenol was higher than benzene.

SOA from aromatic hydrocarbons formed under low $\mathrm{NO}_{\mathrm{x}}$ conditions was previously reported to be effectively nonvolatile (Ng et al., 2007), in which case SOA yield would be independent of particle mass concentration (flat SOA yield curves). However, for benzene, $o-/ m$-cresol, and possibly DMPs, the SOA yield was observed to be slightly dependent on particle concentration. Therefore, in this study, constant SOA yield was not assumed and a one product model fit was applied to perform calculation of the contribution of phenolic route in the following section. 
Table 1. Experimental test matrix $\left(\right.$ low $\left.\mathrm{NO}_{\mathrm{x}}\right)$.

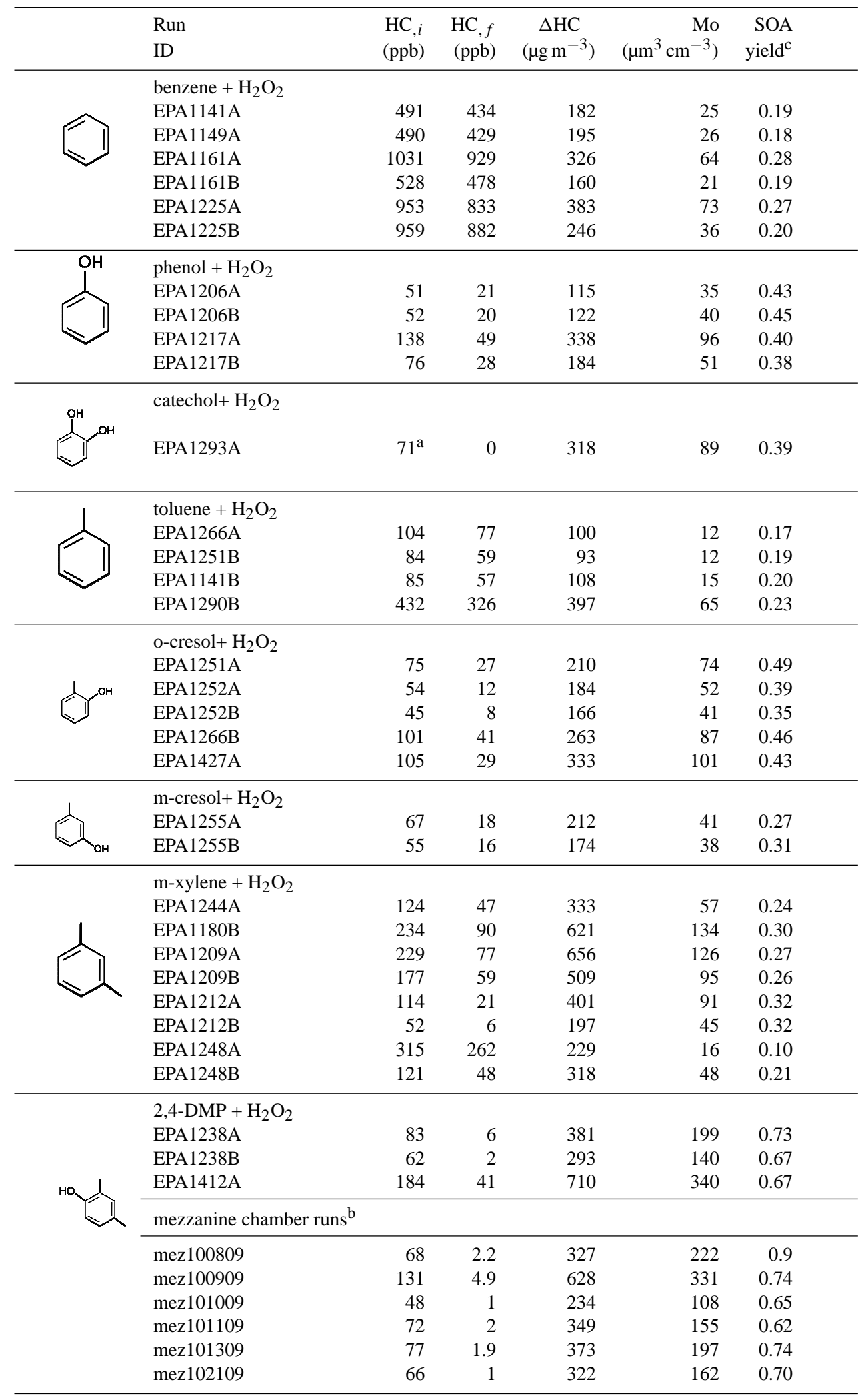


Table 1. Continued.

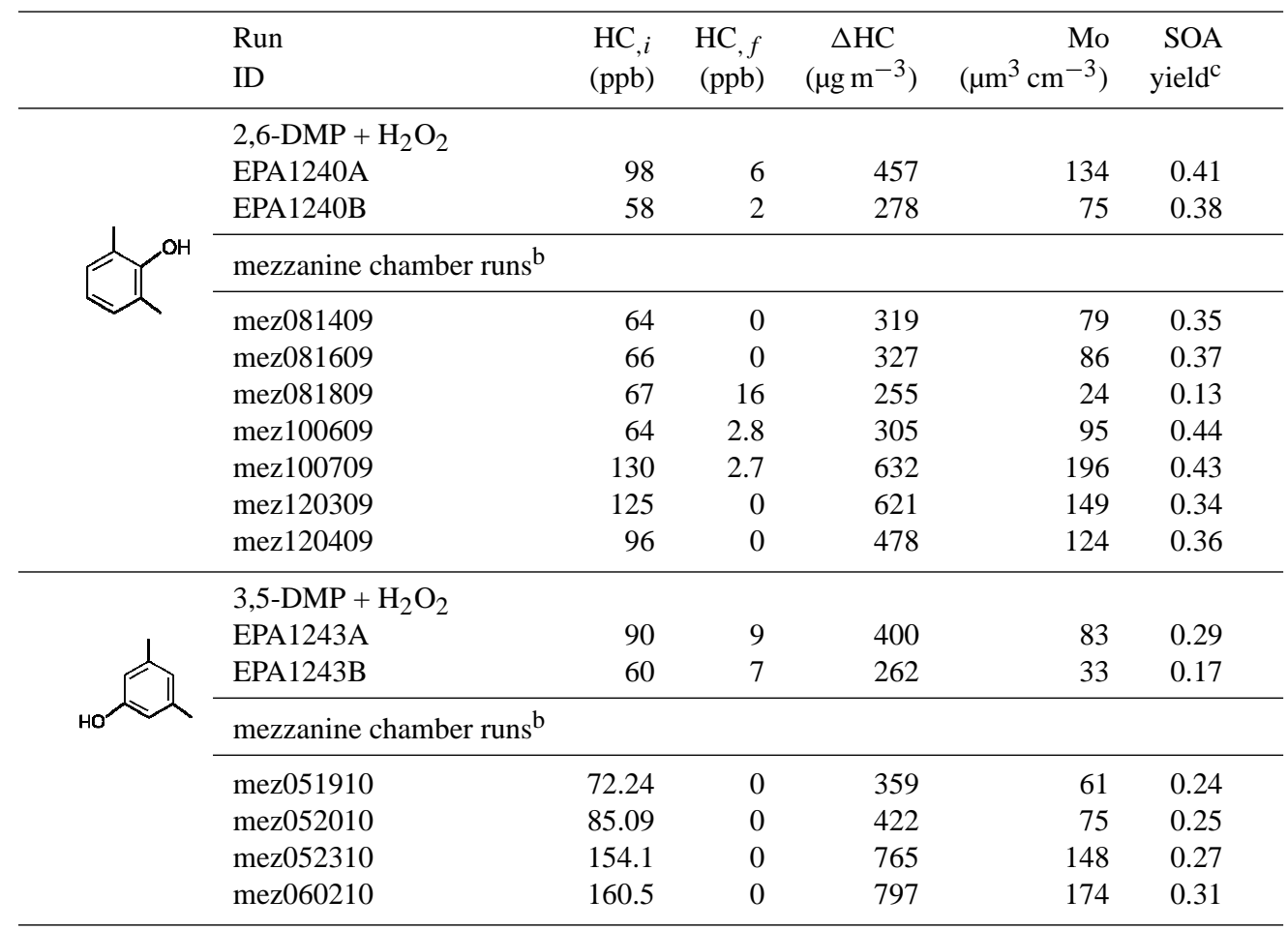

${ }^{\mathrm{a}}$ Initial concentration calculated by amount injected. Injection done with oven temperature $\sim 120^{\circ} \mathrm{C} .{ }^{\mathrm{b}}$ Initial DMPs concentrations calculated based on injection. Final concentration obtained by the PTR-MS. ${ }^{c}$ yields calculated using SOA density $1.4 \mathrm{~g} \mathrm{~cm}^{-3}$.

\subsection{Contribution of phenolic route}

The formation yields of phenolics from aromatics were obtained. An example for $o$-cresol and $m / p$-cresol formation from toluene is shown in Fig. 2. The cresol formation yields from toluene were calculated from measured cresol by correcting for the further reaction of cresols with $\mathrm{OH}$. Equations in Atkinson et al. (1982) and rate constants from Calvert et al. (2002) were used for the correction. Phenol, cresols, and DMPs formation yields are in reasonable agreement with previous studies (Table 2) (Atkinson, 1989; Atkinson et al., 1991; Berndt and Böge, 2006; Klotz et al., 1998; Noda et al., 2009; Smith et al., 1999; Smith et al., 1998; Volkamer et al., 2002).

Contributions of the phenolic route to aromatic SOA formation in the low $\mathrm{NO}_{\mathrm{x}}$ system were estimated by combining SOA yield measurement (Fig. 1), phenolic yields, and consumption of phenolics (e.g., Fig. 2). The amount of phenolics (as products) reacted is calculated as the gap between the observed concentration of phenolic compounds and the concentration corrected for the secondary reaction. Phenolic route SOA is calculated by multiplying reacted phenolics and their SOA yield at appropriate mass loading using the phenolic SOA yield curves in Fig. 1. SOA yields from cresol isomers $(o-, m-$, and $p-)$ were assumed to be the same (Henry et al., 2008). The ratio of 2,4-DMP and 2,6-DMP produced from
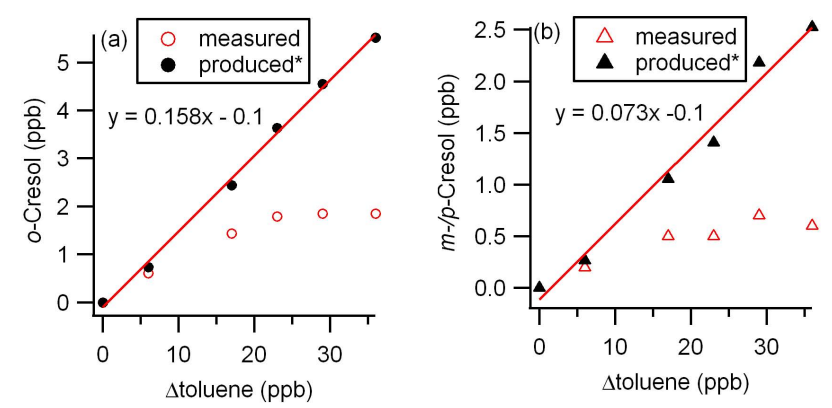

Fig. 2. Formation of cresols from $\mathrm{OH}$ reaction with toluene. *measured cresol concentrations were corrected for secondary reaction.

$\mathrm{OH}$ reaction of $m$-xylene was assumed to be the same as that reported by Smith et al. (1999). Formation of 3,5-DMP is assumed to be insignificant (Smith et al., 1999). Contribution of the phenolic route in the no $\mathrm{NO}_{\mathrm{x}}$ system is summarized in Table 3 . The contribution was approximately $20 \%$ for benzene, toluene, and $m$-xylene in low $\mathrm{NO}_{\mathrm{x}}$ conditions. 
Table 2. Phenolic formation yield from $\mathrm{OH}$ reaction with benzene, toluene, and $m$-xylene.

\begin{tabular}{|c|c|c|c|}
\hline & \multicolumn{2}{|c|}{ Phenolic formation yield (\%) } & $\mathrm{NO}_{\mathrm{x}}(\mathrm{ppm})$ \\
\hline & \multicolumn{2}{|c|}{ Phenol } & \\
\hline This study & \multicolumn{2}{|c|}{41.3} & 0 \\
\hline Berndt and Böge (2006) & \multicolumn{2}{|c|}{$61 \pm 6$} & 0 \\
\hline Volkamer et al. (2002) & \multicolumn{2}{|c|}{$53.1 \pm 6$} & $0.002-2$ \\
\hline & $o$-Cresol & $(m+p)$-Cresol & \\
\hline This study & 15.8 & 7.3 & 0 \\
\hline Atkinson et al. (1989) & $20.4 \pm 2.7$ & $4.8 \pm 0.9$ & $0-10$ \\
\hline Klotz et al. (1998) & $12.0 \pm 1.4$ & $5.9 \pm 0.9$ & $0.003-0.3$ \\
\hline \multirow[t]{2}{*}{ Smith et al. (1998) } & $12.3 \pm 0.6$ & $5.6 \pm 0.4$ & $0.10-0.42$ \\
\hline & \multicolumn{2}{|c|}{$(2,4+2,6+3,5)-\mathrm{DMP}$} & \\
\hline This study* & \multicolumn{2}{|c|}{$8.2 \pm 1.3$} & 0 \\
\hline Smith et al. (1999) & \multicolumn{2}{|c|}{$10.9 \pm 0.5$} & $0.157-1.081$ \\
\hline Atkinson et al. (1991) & \multicolumn{2}{|c|}{$21.0 \pm 5.6$} & $0-10$ \\
\hline Noda et al. (2009) & \multicolumn{2}{|c|}{$14.1 \pm 2.6$} & $0.01-0.1$ \\
\hline
\end{tabular}

* Acquired in mezzanine chamber using PTR-MS.

Table 3. Estimated contribution of phenolic route to benzene, toluene, and $m$-xylene SOA.

\begin{tabular}{lccc}
\hline & Benzene & Toluene & $m$-Xylene \\
\hline $\begin{array}{l}\text { Phenolic } \\
\text { route }(\%)\end{array}$ & $23.5 \pm 4.7 *$ & $15.8 \pm 3.8^{*}$ & $\begin{array}{c}16.9 \pm 3.4 \\
(n=4)\end{array}$ \\
\hline
\end{tabular}

* Error estimated based on repeated m-xylene experiments and phenolic route calculations.

\subsection{Particle chemical composition}

\subsubsection{SOA elemental ratio and density}

The results of elemental analysis of HR-ToF-AMS data $(\mathrm{O} / \mathrm{C}$ ratio) are shown in Fig. 3. The $\mathrm{O} / \mathrm{C}$ ratios during the experiments were nearly constant with only a small increase in $\mathrm{O} / \mathrm{C}$ observed over time. The $\mathrm{O} / \mathrm{C}$ ratio decreased as the number of methyl substituents on the parent aromatic ring increased; $\sim 0.6$ for $\mathrm{C}_{6}$ species (benzene, phenol, and catechol), $\sim 0.5$ for $\mathrm{C}_{7}$ species (toluene and cresols), and $\sim 0.4$ for $\mathrm{C}_{8}$ species ( $m$-xylene and dimethylphenols). The decrease in $\mathrm{O} / \mathrm{C}$ is approximately consistent with the increasing number of carbons in the parent aromatics, indicating that the methyl substituents did not play a major role in the SOA formation mechanism. Therefore the $\mathrm{H}$-abstraction from methyl substituents is not likely to be an important route to aromatic $\mathrm{SOA}$ formation under low $\mathrm{NO}_{\mathrm{x}}$ conditions. The $\mathrm{O} / \mathrm{C}$ ratios of SOA between aromatic hydrocarbons and corresponding phenolics were similar, suggesting the significance of multigenerational reactions.

Real-time SOA density measured by the APM-SMPS is shown in Fig. 4. The SOA densities were observed to be

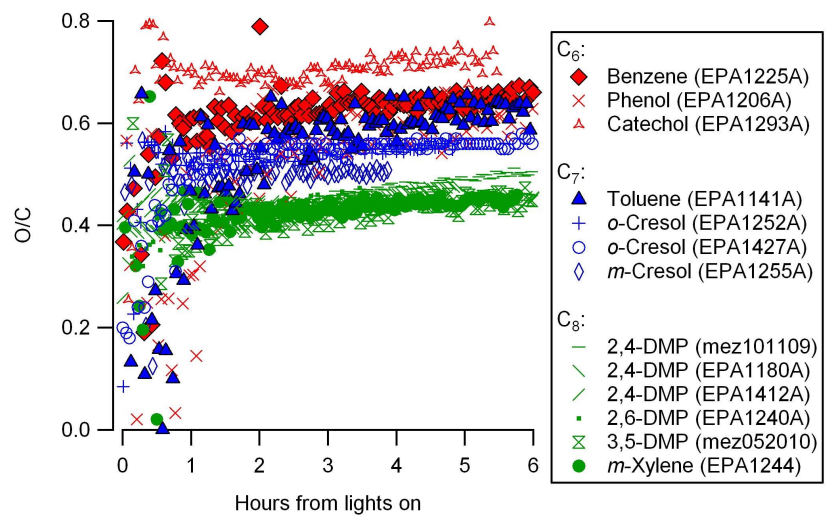

Fig. 3. Time series of the $\mathrm{O} / \mathrm{C}$ ratio of SOA formed from aromatic hydrocarbons and phenolic compounds.

initially high $\left(\sim 1.8 \mathrm{~g} \mathrm{~cm}^{-3}\right)$, which could be due to high density of nucleating species. The final SOA densities were in the range of $1.3-1.4 \mathrm{~g} \mathrm{~cm}^{-3}$, in reasonable agreement with previous studies (Ng et al., 2007; Sato et al., 2010). Although Bahreini et al. (2005) observed weak correlation between effective density and relative contribution of $\mathrm{m} / \mathrm{z} 44$ signal to total organic signal of AMS, the final SOA densities were found to be independent of elemental composition of SOA from aromatics tested in this study (Fig. 5). Therefore a constant SOA density $\left(1.4 \mathrm{~g} \mathrm{~cm}^{-3}\right)$ is applied to all the experiments in this study.

\subsubsection{Filter analysis}

Chemical composition of SOA was analyzed by off-line filter analysis. Samples were directly infused to the 


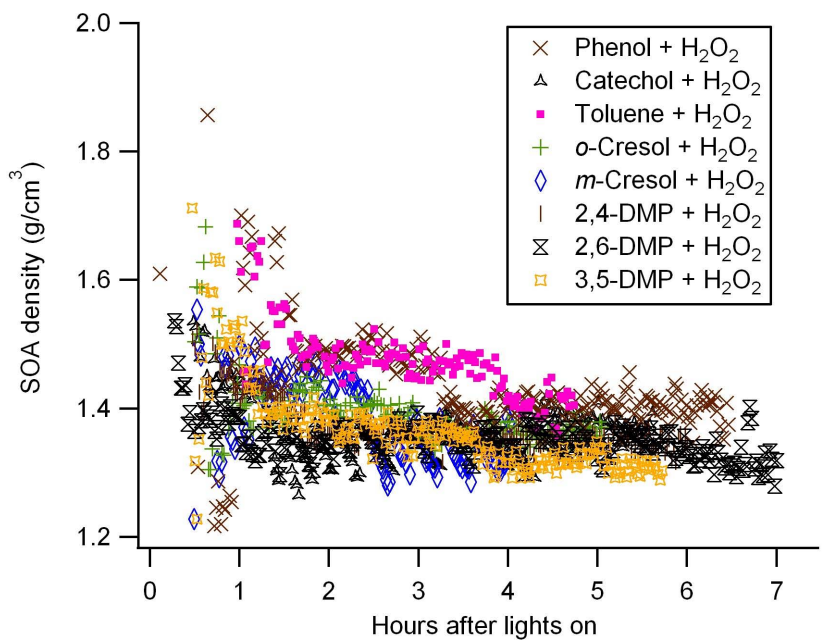

Fig. 4. Time series of the density of SOA formed from aromatic hydrocarbons and phenolic compounds.

ESI/APCI-TOFMS. Although direct infusion of SOA extract into ESI-MS is often done (e.g., Altieri et al., 2006; Camredon et al., 2010; De Haan et al., 2009; Heaton et al., 2009), caution must be taken in interpreting the mass spectrums due to possible formation of adducts or analyte-solvent reaction products (Bateman et al., 2008; Pratt and Prather, 2011). Mass spectra obtained by ESI/APCI-TOFMS are shown in Fig. 6. High mass accuracy measurements enabled determination of empirical formula typically within $5 \mathrm{ppm}$ mass error. Inclusion of nitrogen or halogens in the formula calculation did not yield reasonable formulae. Major ions in each spectrum contained the same number of carbon as reactants (e.g., $\mathrm{C}_{6} \mathrm{H}_{8} \mathrm{O}_{6}$ from phenol, $\mathrm{C}_{7} \mathrm{H}_{10} \mathrm{O}_{6}$ from $o$-cresol, and $\mathrm{C}_{8} \mathrm{H}_{12} \mathrm{O}_{6}$ from 2,4-DMP).

The possibility of adduct formation between acetic acid mobile phase modifier and analytes was investigated by changing acetic acid to formic acid; however, the major signals were still the same, indicating that the observed products are not adducts of the acid modifier. Acetonitrile was used in this study instead of methanol to reduce the risk of analytesolvent reactions (particularly reactions of methanol and carbonyls or carboxylic acids) (Bateman et al., 2008). Tests substituting methanol as an organic solvent did not alter the major MS signal distribution indicating those MS signals did not result from analyte-solvent reaction. The agreement of carbon number and apparent $\mathrm{CH}_{2}$ shift with increasing number of methyl substituents on the aromatic precursor suggests that these major signals are not likely to be adducts formed during ionization.

Since only formulae were determined and no structural information is available in this study, there are a number of possible structures such as unsaturated multi-functional ringopening products (e.g., diacids, polyols). Although column separation using different types of reverse-phase column was

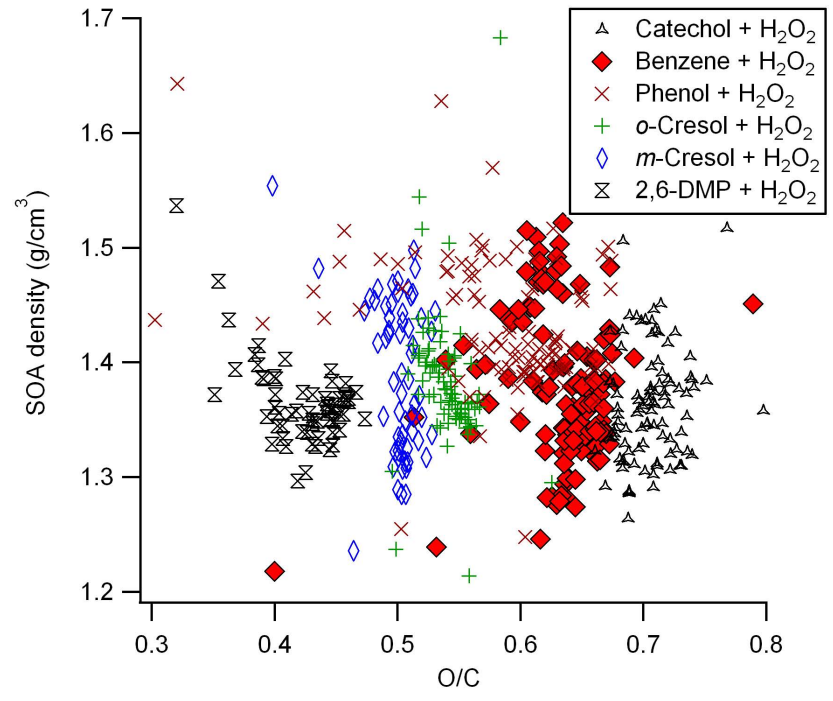

Fig. 5. The relationship between density and elemental compositions of SOA formed from aromatic hydrocarbons and phenolic compounds.

attempted, most of the major signals appeared in the nonretained peak, indicating that these species were too polar to be retained by conventional reversed-phase columns.

Another possible reaction products consistent with these formulae of the major signals are the bicyclic hydroperoxides formed from the reaction of $\mathrm{HO}_{2}$ and bicyclic peroxy radicals (Fig. 7). The formation of bicyclic peroxy radicals intermediate from $\mathrm{OH}$-initiated reaction of aromatic hydrocarbons in gas-phase has been reported experimentally and theoretically (Andino et al., 1996; Birdsall et al., 2010; Birdsall and Elrod, 2011; Glowacki et al., 2009; Huang et al., 2008; Wyche et al., 2009). Johnson et al. (2004, 2005) predicted bicyclic hydroperoxides as one of the predominant aerosol species from aromatic hydrocarbons. Currently, organic peroxides such as hydroperoxides and peroxyhemiacetals have been suggested to be important component of SOA (e.g., monoterpene ozonolysis; Docherty et al., 2005, isoprene photooxidation; Surratt et al., 2006, naphthalene photooxidation; Kautzman et al., 2010, and toluene photooxidation; Sato et al., 2007). Reinnig et al. (2008) reported that the parent ion from two hydroperoxide surrogates, cumene hydroperoxide and tert-butylhydroperoxide were not seen by either negative or positive mode ESI and APCI. Further, only fragments for cumene hydroperoxide were observed for ESI and APCI operating only in the positive mode and for tert-butylhydroperoxide only in the positive APCI mode. This poses an uncertainty in our detection of bicyclic hydroperoxide in this study; however, since the tentatively proposed bicyclic hydroperoxide are highly oxidized and multifunctional (with an oxygen-bridge), other functional groups may enable the ionization. 


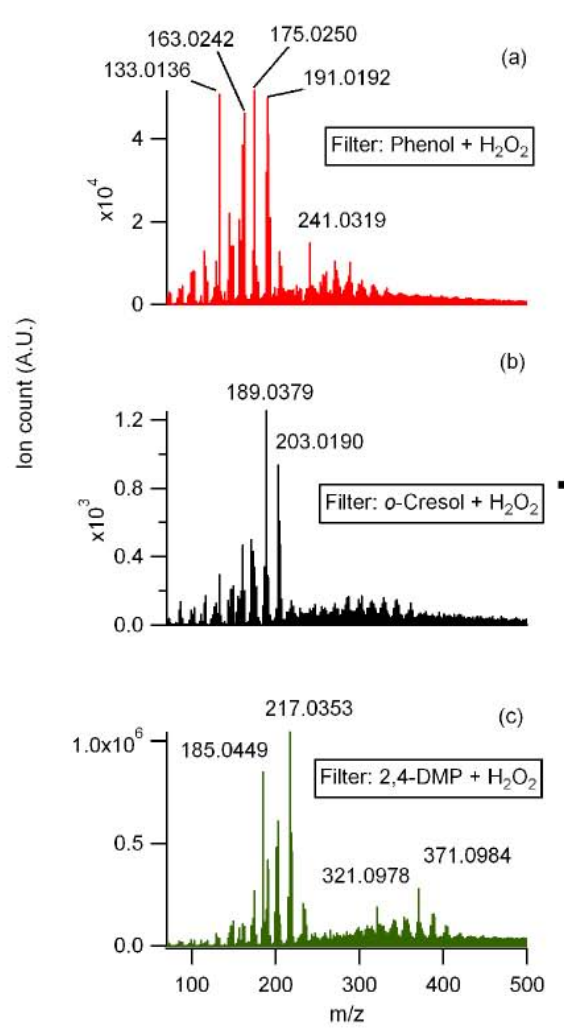

$\left(a^{\prime}\right)$
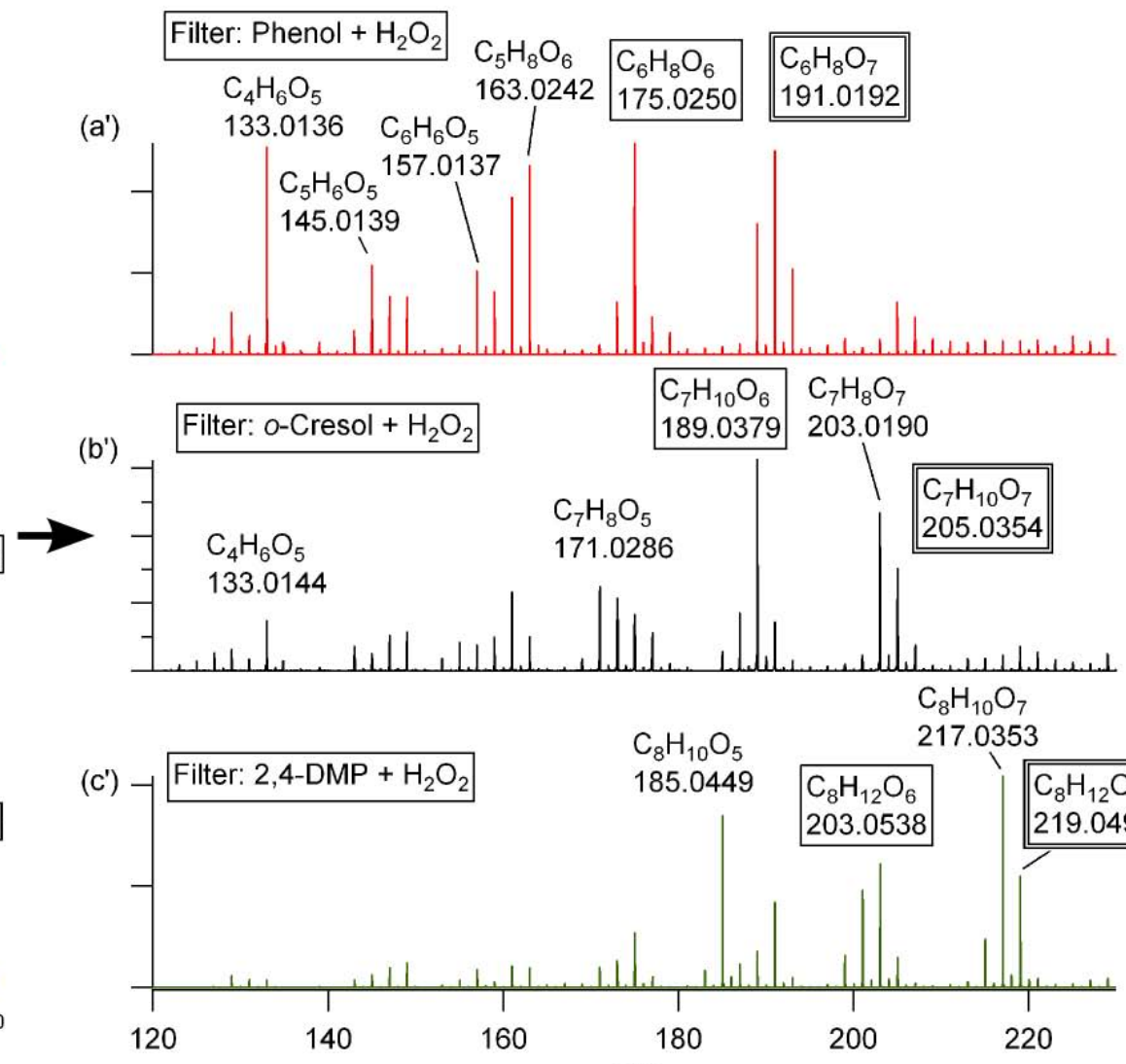

$\mathrm{C}_{8} \mathrm{H}_{10} \mathrm{O}_{5}$ 217.0353
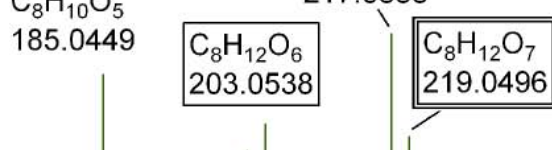

Fig. 6. ESI/APCI-ToF mass spectrums of SOA formed by OH reaction with phenolic compounds.

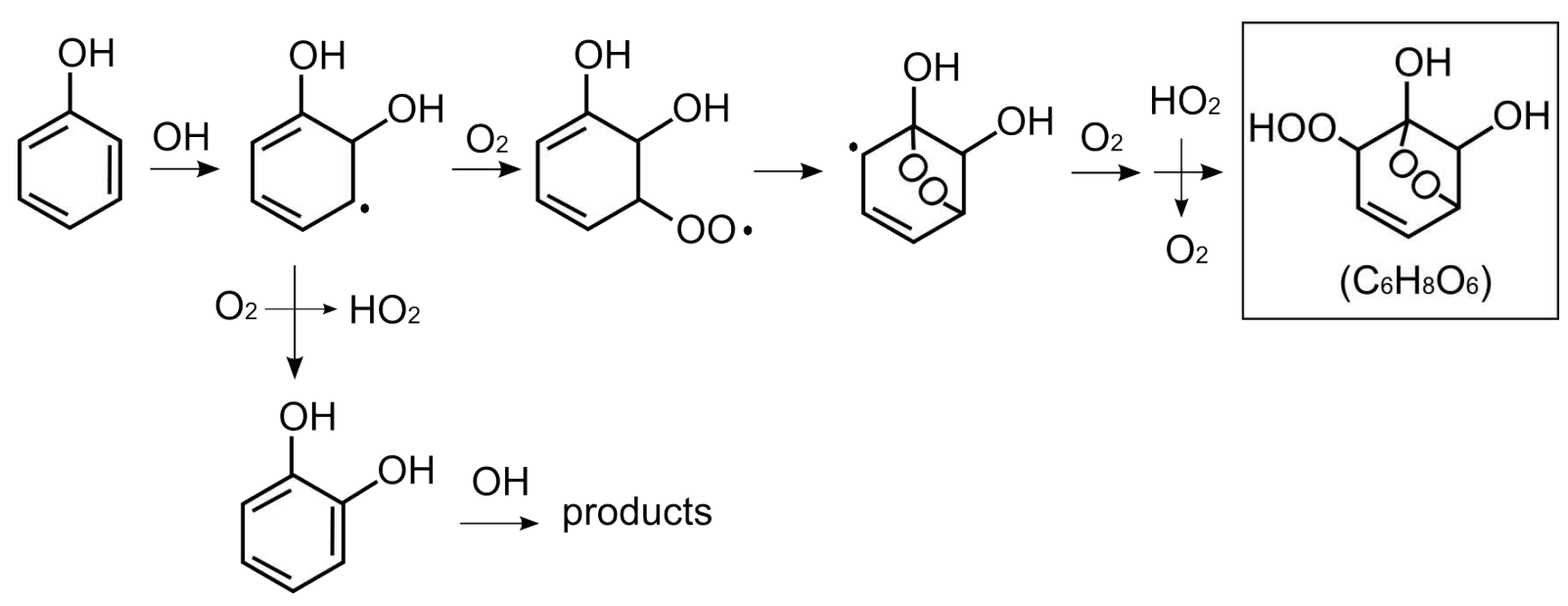

Fig. 7. Possible formation pathway of a bicyclic hedroperoxide $\left(\mathrm{C}_{6} \mathrm{H}_{8} \mathrm{O}_{6}\right)$ from $\mathrm{OH}$ reaction with phenol in the absence of $\mathrm{NO}_{\mathrm{x}}$ inferred from aromatics oxidation mechanisms (e.g., Calvert et al., 2002; Johnson et al., 2005). Catechol formation from phenol is reported to be approximately $80 \%$ (Olariu et al., 2002).

The presence of peroxides was investigated by conducting phenol photooxidation experiments under excess NO. In excess NO condition, the (bicyclic) peroxy radicals rapidly react with NO to form the alkoxy radical, which is suggested to undergo decomposition (Atkinson, 2000; Calvert et al., 2002). The resulting mass spectrum (after separating nitrophenolic species by a reverse phase column; not shown) indicated $\mathrm{C}_{6} \mathrm{H}_{8} \mathrm{O}_{6}$ and $\mathrm{C}_{6} \mathrm{H}_{8} \mathrm{O}_{7}$ were still present, suggesting 


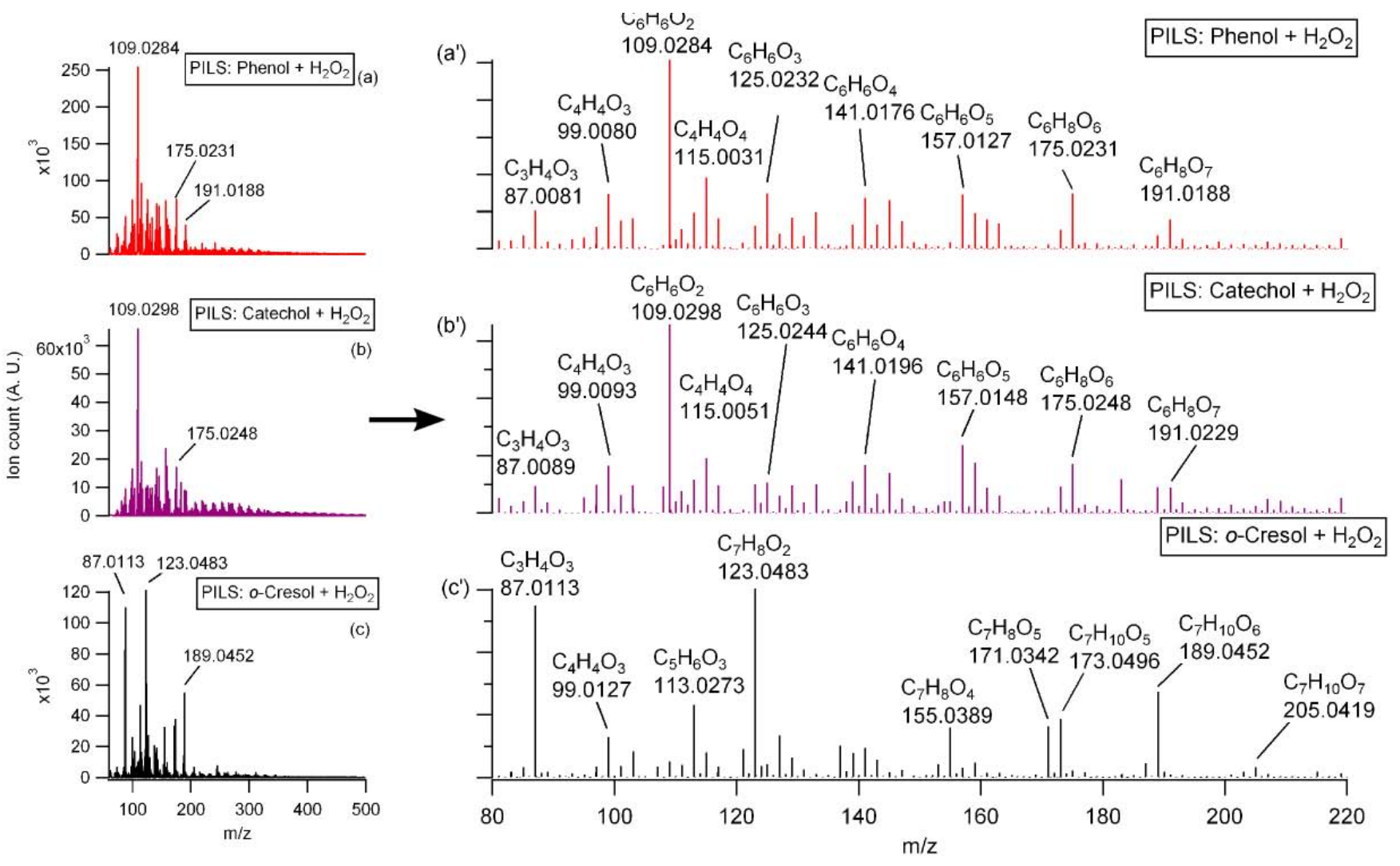

Fig. 8. PILS-ESI-ToF mass spectrums of SOA formed by OH reaction with phenolic compounds. (The spectrum for phenol (a) and catechol (b) is taken when SOA concentration was highest. For $o$-cresol (c), spectrum at highest $\mathrm{C}_{7} \mathrm{H}_{8} \mathrm{O}_{2}$ is shown.)

that at least some fraction of $\mathrm{C}_{6} \mathrm{H}_{8} \mathrm{O}_{6}$ and $\mathrm{C}_{6} \mathrm{H}_{8} \mathrm{O}_{7}$ are formed via a non-peroxy radical route. Although uncertainty remains, it is still interesting that major signals in ESI/APCITOFMS matched the widely recognized bicyclic hydroperoxides. Additional analytical techniques, such as column separation of the highly polar species, derivatization, MS/MS or NMR, are necessary for unambiguous identification of the products.

\subsubsection{PILS-TOFMS}

Mass spectra obtained by PILS-ESI-TOFMS of SOA formed from $\mathrm{OH}$ reaction with phenol, catechol, and $o$-cresol are shown in Fig. 8. Major signals observed from off-line filter analysis were also observed by the on-line PILS-TOFMS such as $m / z 175$ and 191 from the phenol SOA mass spectrum (Fig. 8a). Since the PILS-TOFMS was operated without a denuder upstream, water soluble gas-phase compounds can potentially be collected by the PILS system. The highest signal in Fig. 8a (mass spectrum when SOA was highest), $m / z, 109$ is catechol $\left(\mathrm{C}_{6} \mathrm{H}_{6} \mathrm{O}_{2}\right)$, which is consistent with previous gas-phase studies $(80.4 \%$ yield from phenol, Olariu et al., 2002). From $o$-cresol, methylcatechol ( $\mathrm{m} / \mathrm{z}, 123)$ was observed. Although further reaction mechanisms of catechol species is highly uncertain, a series of signals consistent with $-\mathrm{OH}$ addition to catechol was observed $\left(\mathrm{C}_{6} \mathrm{H}_{6} \mathrm{O}_{2}, \mathrm{C}_{6} \mathrm{H}_{6} \mathrm{O}_{3}\right.$, $\mathrm{C}_{6} \mathrm{H}_{6} \mathrm{O}_{4}, \mathrm{C}_{6} \mathrm{H}_{6} \mathrm{O}_{5}$ ), which could imply successive addition of $-\mathrm{OH}$ group to the aromatic ring. Although the absence of column separation before TOFMS may introduce adduct formation, the agreement between carbon number of major products and reactants is obvious, and hence the major signals are unlikely to be artifacts. Additionally, the agreement between off-line filter samples and on-line PILS indicates that the major signals from off-line filter analysis are not likely to be artifacts formed during filter collection.

\section{Conclusions}

The significance of phenolic compounds as intermediate species of aromatic SOA and possible SOA formation mechanism in the absence of $\mathrm{NO}_{\mathrm{x}}$ was investigated using the UCR/CE-CERT Environmental Chamber. SOA formation yield measurements coupled to gas-phase yield measurements indicate that approximately $20 \%$ of the SOA of benzene, toluene, and $m$-xylene could be ascribed to the phenolic route. Initial SOA densities were as high as approximately $1.8 \mathrm{~g} \mathrm{~cm}^{-3}$ and eventually reached the range of $1.3-1.4 \mathrm{~g} \mathrm{~cm}^{-3}$, independent of elemental ratio $(\mathrm{O} / \mathrm{C})$ of 
SOA tested in this study. The major products observed by ESI/APCI-TOFMS contained the same number of carbons as parent aromatics. Major signals from on-line PILS-TOFMS and off-line filter analysis agreed, with some additional possible water soluble gas phase products observed by PILSTOFMS such as catechol.

Acknowledgements. We gratefully acknowledge funding support from University of California Transportation Center, W. M. Keck Foundation, National Science Foundation (ATM-0449778 and ATM-0901282), California Air Resources Board, and University of California, Riverside, Department of Chemical and Environmental Engineering. We also acknowledge Kurt Bumiller and Charles Bufalino for experimental setup, William P. L. Carter and Gookyoung Heo for helpful discussions, Li Qi for helping preliminary experiments, Norman Ho and Mary Kacarab for chemical analysis.

Edited by: N. M. Donahue

\section{References}

Aiken, A. C., DeCarlo, P. F., Kroll, J. H., Worsnop, D. R., Huffman, J. A., Docherty, K., Ulbrich, I., Mohr, C., Kimmenl, J. R., Sun, Y., Zhang, Q., Trimborn, A. M., Northway, M., Ziemann, P. J., Canagaratna, M. R., Onasch, T. B., Alfarra, M. R., Prevot, A. S., Dommen, J., Duplissy, J., Metzger, A., Baltensperger, U., and Jimenez, J. L.: O/C and OM/OC ratios of primary, secondary, and ambient organic aerosols with High-Resolution Time-of-Flight Aerosol Mass Spectrometry, Environ. Sci. Technol., 42, 4487-4485, 2008.

Altieri, K. E., Carlton, A. G., Lim, H.-H., Turpin, B. J., and Seitzinger, S. P.: Evidence for oligomer formation in clouds: Reactions of isoprene oxidation products, Environ. Sci. Technol., 40, 4956-4960, 2006.

Andino, J. M., Smith, J. N., Flagan, R. C., Goddard, W. A., and Seinfeld, J. H.: Mechanism of atmospheric photooxidation of aromatics: A theoretical study, J. Phys. Chem., 100, 10967-10980, 1996.

Arey, J., Obermeyer, G., Aschmann, S. M., Chattopadhyay, S., Cusick, R. D., and Atkinson, R.: Dicarbonyl products of the $\mathrm{OH}$ radical-initiated reaction of a series of aromatics hydrocarbons. Environ. Sci. Technol., 43, 683-689, 2009.

Atkinson, R.: Kinetics and mechanisms of the gas-phase reactions of the hydroxyl radical with organic compounds, J. Phys. Chem. Ref. Data Monograph, 1, 1-246, 1989.

Atkinson, R.: Atmospheric chemistry of VOCs and NOx, Atmos. Environ., 34, 2063-2101, 2000.

Atkinson, R., Aschmann, S. M., Carter, W. P. L., Winer, A. M., and Pitts, J. N.: Alkyl nitrate formation from the $\mathrm{NO}_{\mathrm{x}}-$ air photooxications of C2-C8 n-alkanes, J. Phys. Chem., 86, 4563-4569, 1982.

Atkinson, R., Aschmann, S. M., and Arey, J.: Formation of ringretaining products from the $\mathrm{OH}$ radical-initiated reactions of $\mathrm{o}$-, m-, and p-xylene, Int. J. Chem. Kinet., 23, 77-97, 1991.

Bahreini, R., Keywood, M. D., Ng, N. L., Varutbangkul, V., Gao, H., Flagan, R. C., Seinfeld, J. H., Worsnop, D. R., and Jimenez, J. L.: Measurements of secondary organic aerosol form oxidation of cycloalkenes, terpenes, and m-xylene using an Aerodyne
Aerosol Mass Spectrometer, Environ. Sci. Technol., 39, 56745688, 2005.

Bateman, A. P., Walser, M. L., Desyaterik, Y., Laskin, J., Laskin, A., and Nizkorodov, S. A.: The effect of solvent on the analysis of secondary organic aerosol using electrospray ionization mass spectrometry. Environ. Sci. Technol., 42, 7341-7346, 2008.

Bateman, A. P., Nizkorodov, S. A., Laskin, J., and Laskin, A.: Highresolution electospray ionization mass spectrometry analysis of water-soluble organic aerosol collected with a particle into liquid sampler, Anal. Chem., 82, 8010-8016, 2010.

Berndt, T. and Böge, O.: Formation of phenol and carbonyls from the atmospheric reaction of $\mathrm{OH}$ radicals with benzene, Phys. Chem. Chem. Phys., 8, 1205-1214, 2006.

Birdsall, A. W. and Elrod, M. J.: Comprehensive NO-Dependent Study of the Products of the Oxidation of Atmospherically Relevant Aromatic Compounds, J. Phys. Chem. A, 115, 5397-5407, 2011.

Birdsall, A. W., Andreoni, J. F., and Elrod, M. J.: Investigation of the role of bicyclic peroxy radicals in the oxidation mechanism of toluene, J. Phys. Chem., 114, 10655-10663, 2010.

Calvert, J. G., Atkinson, R., Becker, K. H., Kamens, R. M., Seinfeld, J. H., Wallington, T. J., and Yarwood, G.: The mechanism of atmospheric oxidation of aromatics hydrocarbons, Oxford University Press, 2002.

Camredon, M., Hamilton, J. F., Alam, M. S., Wyche, K. P., Carr, T., White, I. R., Monks, P. S., Rickard, A. R., and Bloss, W. J.: Distribution of gaseous and particulate organic composition during dark $\alpha$-pinene ozonolysis, Atmos. Chem. Phys., 10, 2893-2917, doi:10.5194/acp-10-2893-2010, 2010.

Carter, W. P. L., Cocker, D. R., Fitz, D. R., Malkina, I. L., Bumiller, K., Sauer, C. G., Pisano, J. T., Bufalino, C., and Song, C.: A new environmental chamber for evaluation of gas-phase chemical mechanisms and secondary aerosol formation, Atmos. Environ., 39, 7768-7788, 2005.

Chang, J. L. and Thompson, A. E.: Characterization of colored products formed during irradiation of aqueous solutions containing $\mathrm{H}_{2} \mathrm{O}_{2}$ and phenolic compounds, Atmos. Environ., 44, 541$551,2010$.

Clark, C. C., Nakao, S., Sato, K., Qi, L., Asa-Awuku, A., and Cocker III, D. R.: Chemical Characterization by Particle into Liquid Sampling Directly Coupled to an Accurate Mass Time-ofFlight Mass Spectrometer (PILS-ToFMS) of Secondary Organic Aerosol (SOA), in preparation, 2011.

Cocker, D. R., Flagan, R. C., and Seinfeld, J. H.: State-of the art chamber facility for studying atmospheric aerosol chemistry, Environ. Sci. Technol., 35, 2594-2601, 2001.

Coeur-Tourneur, C., Henry, F., Janquin, M.-A., and Brutier, L.: Gas-phase reaction of hydroxyl radicals with $\mathrm{m}-$, o- and $\mathrm{p}$-cresol, Int. J. Chem. Kinet., 38, 553-562, 2006.

Coeur-Tourneur, C., Cassez, A., and Wenger, J. C.: Rate coefficients for the gas-phase reaction of hydroxyl radicals with 2-methoxyphenol (Guaiacol) and related compounds, J. Phys. Chem., 114, 11645-11650, 2010a.

Coeur-Tourneur, C., Foulon, V., and Lareal, M.: Determination of aerosol yields from 3-methylcatechol and 4-methylcatechol ozonolysis in a simulation chamber, Atmos. Environ., 44, 853857, 2010b.

Davidson, C. I., Phalen, R. F., and Solomon, S.: Airborne particulate matter and human health: A review, Aerosol Sci. Technol., 
39, 737-749, 2005.

De Haan, D. O., Corrigan, A. L., Smith, K. W., Stroik, D. R., Turley, J. J., Lee, F. E., Tolbert, M. A., Jimenez, J. L., Cordova, K. E., and Ferrell, G. R.: Secondary Organic Aerosol-Forming Reactions of Glyoxal with Amino Acids, Environ. Sci. Technol., 43, 2818-2824, 2009.

DeCarlo, P. F., Kimmel, J. R., Trimborn, A. M., Northway, M., Jayne, J. T., Aiken, A. C., Gonin, M., Fuhrer, K., Horvath, T., Docherty, K., Worsnop, D. R., and Jimenez, J. L.: Fielddeployable, high-resolution, Time-of-Flight Aerosol Mass Spectrometer, Anal. Chem., 78, 8281-8289, 2006.

Docherty, K. S., Wu, W., Lim, Y. B., and Ziemann, P. J.: Contributions of organic peroxides to secondary aerosol formed from reactions of monoterpenes with $\mathrm{O}_{3}$, Environ. Sci. Technol., 39, 4049-4059, 2005.

Ehara, K., Hagwood, C., and Coakley, K. J.: Novel method to classify aerosol particles according to their mass-to-charge ratioAerosol particle mass analyzer, J, Aerosol Sci., 27, 217-234, 1996.

Eldering, A. and Cass, G. R.: Source-oriented model for air pollutant effects on visibility, J. Geophys. Res., 101, 19343-19369, 1996.

Glowacki, D. R., Wang, L., and Pilling, M. J.: Evidence of formation of bicyclic species in the early stages of atmospheric benzene oxidation, J. Phys. Chem. A, 113, 5385-5396, 2009.

Grosjean, D.: Atmospheric reactions of ortho cresol: Gas phase and aerosol products, Atmos. Environ., 18, 1641-1652, 1984.

Hallquist, M., Wenger, J. C., Baltensperger, U., Rudich, Y., Simpson, D., Claeys, M., Dommen, J., Donahue, N. M., George, C., Goldstein, A. H., Hamilton, J. F., Herrmann, H., Hoffmann, T., Iinuma, Y., Jang, M., Jenkin, M. E., Jimenez, J. L., Kiendler-Scharr, A., Maenhaut, W., McFiggans, G., Mentel, Th. F., Monod, A., Prévôt, A. S. H., Seinfeld, J. H., Surratt, J. D., Szmigielski, R., and Wildt, J.: The formation, properties and impact of secondary organic aerosol: current and emerging issues, Atmos. Chem. Phys., 9, 5155-5236, doi:10.5194/acp-95155-2009, 2009.

Hawthorne, S. B., Krieger, M. S., Miller, D. J., and Mathiason, M. B.: Collection and quantitation of methoxylated phenol tracers for atmospheric pollution from residential wood stoves, Environ. Sci. Technol., 23, 470-475, 1989.

Hawthorne, S. B., Miller, D. J., Langenfeld, J. J., and Krieger, M. S.: PM-10 high-volume collection and quantitation of semi- and nonvolatile phenols, methoxylated phenols, alkanes, and polycyclilc aromatic hydrocarbons from winter urban air and their relationship to wood smoke emissions, Environ. Sci. Technol., 26, 2251-2262, 1992.

Heaton, K. J., Sleighter, R. L., Hatcher, P. G., Hall, W. A., and Johnston, M. V.: Composition domains in monoterpene secondary organic aerosol, Environ. Sci. Technol., 43, 7797-7802, 2009.

Henry, F., Coeur-Tourneur, C., Ledoux, F., Tomas, A., and Menu, D.: Secondary organic aerosol formation from the gas phase reaction of hydroxyl radicals with m-, o- and p-cresol, Atmos. Environ., 42, 3035-3045, 2008.

Huang, M., Zhang, W., Wang, Z., Hao, L., Zhao, W., Liu, X., Long, B., and Fang, L.: Theoretical investigation on the detailed mechanism of the $\mathrm{OH}$-initiated atmospheric photooxidation of o-xylene, Int. J. Quantum Chem., 108, 954-966, 2008.

Hurley, M. D., Sokolov, O., Wallington, T. J., Takekawa, H., Kara- sawa, M., and Klotz, B.: Organic aerosol formation during the atmospheric degradation of toluene, Environ. Sci. Technol., 35, 1358-1366, 2001.

Iinuma, Y., Boge, O., Grafe, R., and Herrmann, F.: Methylnitrocatechols: Atmospheric tracer compounds for biomass burning secondary organic aerosols, Environ. Sci. Technol., 44, 8453-8459, 2010.

IPCC: Intergovernmental Panel on Climate Change: Climate Change 2007: The Physical Science Basis, Cambridge University Press, UK, 2007.

Johnson, D., Jenkin, M., Wirtz, K., and Martin-Reviejo, M.: Simulating the formation of secondary organic aerosol from the photooxidation of toluene, Environ. Chem., 1, 150-165, 2004.

Johnson, D., Jenkin, M. E., Wirtz, K., and Martin-Reviejo, M.: Simulating the formation of secondary organic aerosol from the photooxidation of aromatics hydrocarbons, Environ. Chem., 2, 3548, 2005.

Kanakidou, M., Seinfeld, J. H., Pandis, S. N., Barnes, I., Dentener, F. J., Facchini, M. C., Van Dingenen, R., Ervens, B., Nenes, A., Nielsen, C. J., Swietlicki, E., Putaud, J. P., Balkanski, Y., Fuzzi, S., Horth, J., Moortgat, G. K., Winterhalter, R., Myhre, C. E. L., Tsigaridis, K., Vignati, E., Stephanou, E. G., and Wilson, J.: Organic aerosol and global climate modelling: a review, Atmos. Chem. Phys., 5, 1053-1123, doi:10.5194/acp-5-1053-2005, 2005.

Kautzman, K. E., Surratt, J. D., Chan, M. N., Chan, A. W. H., Hersey, S. P., Chhabra, P. S., Dalleska, N. F., Wennberg, P. O., Flagan, R. C., and Seinfeld, J. H.: Chemical composition of gasand aerosol-phase products from the photooxidation of naphthalene, J. Phys. Chem., 114, 913-934, 2010.

Khalizov, A. F., Zhang, R., Zhang, D., Xue, H., Pagels, J., and McMurry, P. H.: Formation of highly hygroscopic soot aerosols upon internal mixing with sulfuric acid vapor, J. Geophys. Res. 114, D05208, doi:10.1029/2008JD010595, 2009.

Klotz, B., Sorensen, S., Barnes, I., Becker, K. H., Etzkorn, T., Volkamer, R., Platt, U., Wirtz, K., and Martin-Reviejo, M.: Atmospheric oxidation of toluene in a large-volume outdoor photoreactor: In situ determination of ring-retaining product yields, J. Phys. Chem. A, 102, 10289-10299, 1998.

Malloy, Q., Nakao, S., Qi, L., Austin, R. L., Stothers, C., Hagino, H., and Cocker, D. R.: Real-time aerosol density determination utilizing a modified Scanning Mobility Particle Sizer - Aerosol Particle Mass Analyzer system, Aerosol Sci. Technol., 43, 673678, 2009.

McMurry, P. H., Wang, X. W., Park, K., and Ehara, K.: The relationship between mass and mobility for atmospheric particles: A new technique for measuring particle density, Aerosol Sci. Technol., 36, 227-238, 2002.

Nakao, S., Shrivastava, M., Nguyen, A., Jung, H., and Cocker, D.: Interpretation of Secondary Organic Aerosol Formation from Diesel Exhaust Photooxidation in an Environmental Chamber, Aerosol Sci. Technol., 45, 954-962, 2011.

Ng, N. L., Kroll, J. H., Chan, A. W. H., Chhabra, P. S., Flagan, R. C., and Seinfeld, J. H.: Secondary organic aerosol formation from $m$-xylene, toluene, and benzene, Atmos. Chem. Phys., 7, 3909-3922, doi:10.5194/acp-7-3909-2007, 2007.

Noda, J., Volkamer, R., and Molina, M. J.: Dealkylation of alkylbenzenes: A significant pathway in the toluene, $o-, m-, p$-xylene + OH reaction, J. Phys. Chem. A, 113, 9658-9666, 2009. 
Odum, J. R., Hoffman, T., Bowman, F., Collins, D., Flagan, R. C., and Seinfeld, J. H.: Gas/particle partitioning and secondary organic aerosol yields, Environ. Sci. Technol., 30, 2580-2585, 1996.

Olariu, R. I., Klotz, B., Barnes, I., Becker, K. H., and Mocanu, R.: FT-IR study of the ring-retaining products from the reaction of $\mathrm{OH}$ radicals with phenol, o-, m-, and p-cresol, Atmos. Environ., 36, 3685-3697, 2002.

Orsini, D. A., Ma, Y., Sullivan, A., Sierau, B., Baumann, K., and Weber, R. J.: Refinements to the particle-into-liquid sampler (PILS) for ground and airborne measurements of water soluble aerosol composition, Atmos. Environ., 37, 1243-1259, 2003.

Pope, C. A. and Dockery, D. W.: Health effects of fine particulate air pollution: Lines that connect, J. Air Waste Manage. Assoc., 56, 709-742, 2006.

Pratt, K. A. and Prather, K. A.: Mass spectrometry of atmospheric aerosols - recent developments and applications, Part I: Offline mass spectrometry techniques, Mass Spectromet. Rev., 116, doi:10.1002/mas.20322, 2011.

Reinnig, M.-C., Müller, L., Warnke, J., and Hoffmann, T.: Characterization of selected organic compound classes in secondary organic aerosol from biogenic VOCs by HPLC/MSn, Analyt. Bioanaly. Chem., 391, 171-182, 2008.

Sato, K., Hatakeyama, S., and Imamura, T.: Secondary organic aerosol formation during the photooxidation of toluene: $\mathrm{NO}_{\mathrm{x}}$ dependence of chemical composition, J. Phys. Chem. A, 111, 9796-9808, 2007.

Sato, K., Takami, A., Isozaki, T., Hikida, T., Shimono, A., and Imamura, T.: Mass spectrometric study of secondary organic aerosol formed from the photo-oxidation of aromatic hydrocarbons. Atmos. Environ., 44, 1080-1087, 2010.

Schauer, J. J., Kleeman, M. J., Cass, G. R., and Simoneit, B. R. T.: Measurement of emissions from air pollution sources, 3. C1-C29 organic compounds from fireplace combustion of wood, Environ. Sci. Technol., 35, 1716-1728, 2001.

Simoneit, B. R. T.: A review of biomarker compounds as source indicators and tracers for air pollution, Environ. Sci. Pollut. Res., 6, 159-169, 1999.
Smith, D. F., McIver, C. D., and Kleindienst, T. E.: Primary product distribution from the reaction of hydroxyl radicals with toluene at ppb $\mathrm{NO}_{\mathrm{x}}$ mixing ratios, J. Atmos. Chem., 30, 209-228, 1998.

Smith, D. F., Kleindienst, T. E., and McIver, C. D.: Primary product distributions from the reaction of $\mathrm{OH}$ with $\mathrm{m}$-, p-xylene, 1,2,4- and 1,3,5-trimethylbenzene, J. Atmos. Chem., 34, 339364, 1999.

Sun, Y. L., Zhang, Q., Anastasio, C., and Sun, J.: Insights into secondary organic aerosol formed via aqueous-phase reactions of phenolic compounds based on high resolution mass spectrometry, Atmos. Chem. Phys., 10, 4809-4822, doi:10.5194/acp-104809-2010, 2010.

Surratt, J. D., Murphy, S. M., Kroll, J. H., Ng, N. L., Hildebrandt, L., Sorooshian, A., Szmigielski, R., Vermeylen, R., Maenhaut, W., Claeys, M., Flagan, R. C., and Seinfeld, J. H.: Chemical composition of secondary organic aerosol formed from the photooxidation of isoprene, J. Phys. Chem. A, 110, 9665-9690, 2006.

Takekawa, H., Minoura, H., and Yamazaki, S.: Temperature dependence of secondary organic aerosol formation by photo-oxidation of hydrocarbons, Atmos. Environ., 37, 3413-3424, 2003.

Volkamer, R., Klotz, B., Barnes, I., Imamura, T., and Washida, N.: $\mathrm{OH}$-initiated oxidation of benzene Part 1, Phenol formation under atmospheric conditions, Phys. Chem. Chem. Phys., 4, 15981610, 2002.

Weber, R. J., Orsini, D. A., Daun, Y., Lee, Y.-N., Klotz, P. J., and Brechtel, F.: A particle-into-liquid collector for rapid measurement of aerosol bulk chemical composition, Aerosol Sci. Technol., 35, 718-727, 2001.

Wyche, K. P., Monks, P. S., Ellis, A. M., Cordell, R. L., Parker, A. E., Whyte, C., Metzger, A., Dommen, J., Duplissy, J., Prevot, A. S. H., Baltensperger, U., Rickard, A. R., and Wulfert, F.: Gas phase precursors to anthropogenic secondary organic aerosol: detailed observations of 1,3,5-trimethylbenzene photooxidation, Atmos. Chem. Phys., 9, 635-665, doi:10.5194/acp-9-635-2009, 2009.

Xue, H., Khalizov, A. F., Wang, L., Zheng, J., and Zhang, R.: Effects of coating of dicarboxylic acids on the mass-mobility relationship of soot particles, Environ. Sci. Technol., 43, 2787-2792, 2009. 